\title{
Research Article \\ Relationship between Sowing Time, Variety, and Quality in Safflower
}

\author{
Mehmet Oz \\ Uludag University, Mustafakemalpasa Vocational School, 16500 Bursa, Turkey \\ Correspondence should be addressed to Mehmet Oz; momer@uludag.edu.tr
}

Received 23 March 2016; Accepted 20 July 2016

Academic Editor: Maria Roca

Copyright ( 2016 Mehmet Oz. This is an open access article distributed under the Creative Commons Attribution License, which permits unrestricted use, distribution, and reproduction in any medium, provided the original work is properly cited.

\begin{abstract}
This research was carried out to determine the rates of protein and oil production and fatty acid composition and their correlation coefficients in four safflower cultivars (Remzibey, Dincer, Balci, and Yenice) sown in the autumn and spring from 2013 to 2015 . The experiment was carried out using split plots in a randomized block design and was replicated 3 times. The study found protein production rates between 15.20 and $18.08 \%$, oil production rates between 24.58 and $31.99 \%$, palmitic acid production rates between 5.93 and 7.01\%, stearic acid production rates between 2.13 and $2.53 \%$, oleic acid production rates between 12.08 and $31.58 \%$, linoleic acid production rates between 78.61 and $59.08 \%$, and linolenic acid production rates between 0.11 and $0.15 \%$. Higher seed oil content values were obtained from spring sowing compared to autumn sowing (27.42\% and $26.10 \%)$, and, in terms of both the evaluated sowing times and cultivars, the highest oil production rates were found in the Balci cultivar (32.20\% and 31.78\%) for both sowing times. It was determined that there is a positive and significant $\left(r=0.476^{* *}\right)$ relationship between oil with protein production rates but a negative and significant relationship between oil and linolenic acid production rates $\left(r=-0.728^{* *}\right)$. The oleic acid production rate was strongly negatively and significantly correlated with the linoleic acid production rate $\left(r=-0.997^{* *}\right)$.
\end{abstract}

\section{Introduction}

Safflower is an annual oil plant belonging to the Compositae family that can be grown as a summer or winter crop. The seeds are composed of between 20 and $45 \%$ oil and $15-20 \%$ protein, and the food value of the protein derived from the seeds is high [1]. Safflower oil is odorless and quite rich in linoleic acid from unsaturated oil, which prevents the formation of high cholesterol in the blood [2]. Furthermore, the pulp remaining after seed extraction is used in the production of animal feed, and the crop is highly resistant to drought and extreme temperatures [3]. There are both spiny and spineless types of safflower, and the oil contents of the spiny types are higher than those of the spineless types [4]. Finally, safflower can also be grown successfully on soil with poor fertility [5].

While the global safflower sowing area is 782641 ha, its production is 647374 tons, and the average yield is $8271 \mathrm{~kg} \mathrm{ha}^{-1}$. In Turkey, the safflower production area is $29292 \mathrm{ha}$; production is approximately 45000 tons, and yield is $1536 \mathrm{~kg}$ per ha [6].
In terms of vegetable oil production, Turkey currently produces approximately $40 \%$ of the self-sufficiency rate, so it is necessary to increase oilseed production to close the deficit. The Food, Agriculture and Livestock Ministry supports and encourages the production of the most valuable safflower. However, although it is very valuable as an oil plant, safflower production has not increased globally or in Turkey due to its relatively low seed oil yield compared to other oil plants [7].

If the sowing time is not well defined, germination can be irregular or may not occur, so sowing time significantly increases safflower yield. Because safflower is more resistant to cold compared to other oil crops, it can be sown in the early spring, and in temperate regions, where winters are not very cold, the most favorable sowing time is autumn. Early sowing is especially important in dry conditions. When sowing is timely and done with varieties that are well adapted to the region, various researchers have noted that the yield, yield components, and quality of safflower are enhanced significantly $[8,9]$.

Safflower oil forms linoleic (18:2) and oleic acid (18:1) from unsaturated fatty acids and palmitic acid (16:0) and 
TABLE 1: Protein and oil rates of safflower seeds sown in the autumn and spring.

\begin{tabular}{|c|c|c|c|c|c|c|c|}
\hline \multirow{2}{*}{ Sowing time } & \multirow{2}{*}{ Varieties } & \multicolumn{3}{|c|}{ Protein production rates } & \multicolumn{3}{|c|}{ Oil production rates } \\
\hline & & 2014 & 2015 & 2014-15 & 2014 & 2015 & 2014-15 \\
\hline \multirow{4}{*}{ Autumn } & Remzibey & $16.46^{\mathrm{bc}}$ & $13.93^{\mathrm{e}}$ & $15.20^{\mathrm{c}}$ & $24.96^{c}$ & $22.46^{\mathrm{d}}$ & $23.71^{\mathrm{bc}}$ \\
\hline & Dincer & $16.70^{\mathrm{bc}}$ & $15.00^{\text {de }}$ & $15.85^{\mathrm{bc}}$ & $25.86^{\mathrm{c}}$ & $20.23^{\mathrm{e}}$ & $23.05^{\mathrm{c}}$ \\
\hline & Balci & $16.86^{\mathrm{abc}}$ & $15.40^{\mathrm{cd}}$ & $16.13^{b c}$ & $34.63^{\mathrm{a}}$ & $28.93^{\mathrm{b}}$ & $31.78^{\mathrm{a}}$ \\
\hline & Yenice & $18.30^{\mathrm{a}}$ & $17.66^{\mathrm{ab}}$ & $17.98^{\mathrm{b}}$ & $25.83^{\mathrm{c}}$ & $25.86^{\mathrm{c}}$ & $25.85^{\mathrm{b}}$ \\
\hline \multirow{4}{*}{ Spring } & Remzibey & $16.23^{\mathrm{c}}$ & $15.86^{\mathrm{cd}}$ & $16.05^{\mathrm{bc}}$ & $27.40^{\mathrm{b}}$ & $25.20^{\mathrm{c}}$ & $26.30^{\mathrm{b}}$ \\
\hline & Dincer & $15.60^{c}$ & $15.86^{\mathrm{cd}}$ & $15.73^{\mathrm{bc}}$ & $27.70^{\mathrm{b}}$ & $24.53^{\mathrm{c}}$ & $26.11^{\mathrm{b}}$ \\
\hline & Balci & $17.80^{\mathrm{ab}}$ & $18.36^{\mathrm{a}}$ & $18.08^{\mathrm{a}}$ & $32.13^{\mathrm{a}}$ & $32.26^{\mathrm{a}}$ & $32.20^{\mathrm{a}}$ \\
\hline & Yenice & $17.06^{\mathrm{abc}}$ & $16.76^{\mathrm{bc}}$ & $16.91^{\mathrm{ab}}$ & $25.10^{\mathrm{c}}$ & $25.06^{\mathrm{c}}$ & $25.08^{\mathrm{bc}}$ \\
\hline \multicolumn{8}{|c|}{ Years } \\
\hline & & $16.87^{\mathrm{a}}$ & $16.10^{\mathrm{b}}$ & & $27.95^{\mathrm{a}}$ & $25.57^{\mathrm{b}}$ & \\
\hline \multicolumn{8}{|c|}{ Sowing time } \\
\hline Winter & & $17.08^{\mathrm{a}}$ & $15.50^{\mathrm{b}}$ & 16.29 & 27.82 & $24.37^{\mathrm{b}}$ & $26.10^{\mathrm{b}}$ \\
\hline Summer & & $16.67^{\mathrm{b}}$ & $16.71^{\mathrm{a}}$ & 16.69 & 28.08 & $26.76^{\mathrm{a}}$ & $27.42^{\mathrm{a}}$ \\
\hline \multicolumn{8}{|c|}{ Varieties } \\
\hline Remzibey & & $16.35^{\mathrm{b}}$ & $14.90^{\mathrm{b}}$ & $15.62^{\mathrm{b}}$ & $26.18^{b c}$ & $23.83^{c}$ & $25.00^{\text {bc }}$ \\
\hline Dincer & & $16.15^{\mathrm{b}}$ & $15.43^{\mathrm{b}}$ & $15.79^{\mathrm{b}}$ & $26.78^{b}$ & $22.38^{\mathrm{c}}$ & $24.58^{\mathrm{c}}$ \\
\hline Balci & & $17.33^{\mathrm{a}}$ & $16.88^{\mathrm{a}}$ & $17.10^{\mathrm{a}}$ & $33.38^{\mathrm{a}}$ & $30.60^{\mathrm{a}}$ & $31.99^{\mathrm{a}}$ \\
\hline Yenice & & $17.68^{\mathrm{a}}$ & $17.21^{\mathrm{a}}$ & $17.45^{\mathrm{a}}$ & $25.46^{\mathrm{c}}$ & $25.46^{\mathrm{b}}$ & $25.46^{\mathrm{b}}$ \\
\hline \multicolumn{8}{|c|}{ Significance status } \\
\hline Years (Y) & & - & - & $* *$ & - & - & $* *$ \\
\hline Sowing time (ST) & & * & $* *$ & ns & ns & $* *$ & $* *$ \\
\hline Varieties (V) & & $*$ & $* *$ & $* *$ & $* *$ & $* *$ & $* *$ \\
\hline $\mathrm{Y} \times \mathrm{ST}$ & & - & - & $* *$ & - & - & $* *$ \\
\hline $\mathrm{Y} \times \mathrm{V}$ & & - & - & ns & - & - & $* *$ \\
\hline $\mathrm{ST} \times \mathrm{V}$ & & $* *$ & $* *$ & $* *$ & $* *$ & $* *$ & $* *$ \\
\hline $\mathrm{Y} \times \mathrm{ST} \times \mathrm{V}$ & & - & - & $*$ & - & - & $*$ \\
\hline
\end{tabular}

${ }^{*}$ Significant at level $0.05 ;{ }^{* *}$ significant at level 0.01 . Means shown by the different letters within a column are statistically different.

stearic acid (18:0) from saturated fats. Linoleic acid is the most abundant fatty acid in safflower oil [10].

Liu et al. [11] reported that the maximum oil content in safflower is $32.68 \%$, and there are significant negative relationships between the production rates of oleic acid and linoleic acid rates and significant positive relationships among oleic acid and linoleic acid with palmitic acid production rates. According to Gecgel et al. [12], spring sowings increased oil and oleic acid rates but reduced linoleic acid rates, so sowing time is a significant factor in oil production and fatty acid composition [13].

Oil production rates from 24.53 to $28.47 \%$ and from 21.23 to $25.76 \%$ were realized from autumn and spring sowings, respectively, and a sowing time $\times$ variety interaction was found to be insignificant with regard to oil production rates. However, stearic acid and linoleic acid production rates were significantly affected by sowing time, and significantly negative correlation coefficients were found between palmitic acid and stearic acid in both autumn and spring sowings. A spring sowing time has been proposed for the conditions in Ankara [2].
In their study of safflower, Golkar et al. [14] reported that the protein contents of the seeds ranged between 13.5 and $25.6 \%$ and increased with late sowing [15]. Sabzalian et al. [16] determined that late sowing changed the minimum and maximum values of some quality traits by $29.20-30.00 \%$ for oil production rates, $5.48-7.59 \%$ for palmitic acid, $1.72-2.86 \%$ for stearic acid, $12.24-15.43 \%$ for oleic acid, $71.05-76.12 \%$ for linoleic acid, and $0.21-0.56 \%$ for linolenic acid. Golkar et al. [14] found significantly negative correlation values between oleic acid and linoleic acid $\left(r=-0.98^{* *}\right)$, oil and stearic acid $\left(r=-0.50^{*}\right)$, and palmitic acid and oleic acid $\left(r=-0.51^{*}\right)$. In contrast, the correlation coefficient between the protein production rate and palmitic acid production rate has been determined to be positive and significant $\left(r=0.54^{*}\right)$.

The oil production rate is higher with autumn sowing relative to spring sowing [17-19]. With autumn sowing, palmitic, stearic, and oleic acid production rates are also higher, and linoleic and linolenic production rates are low [19]. Esendal et al. [18] found a 26.9-35.9\% change in safflower oil production rate. A significant sowing time $x$ variety interaction was found, and the lowest oil production rate occurred in the Yenice variety. According to Arslan and 
TABLE 2: Palmitic and stearic acid composition of safflower seeds sown in the autumn and spring.

\begin{tabular}{|c|c|c|c|c|c|c|c|}
\hline \multirow{2}{*}{ Sowing time } & \multirow{2}{*}{ Varieties } & \multicolumn{3}{|c|}{ Palmitic acid composition } & \multicolumn{3}{|c|}{ Stearic acid composition } \\
\hline & & 2014 & 2015 & 2014-15 & 2014 & 2015 & 2014-15 \\
\hline \multirow{4}{*}{ Autumn } & Remzibey & $6.56^{\mathrm{b}}$ & $6.36^{\text {cde }}$ & $6.46^{\mathrm{c}}$ & $2.46^{\mathrm{a}}$ & $2.36^{\mathrm{bc}}$ & $2.41^{\mathrm{bc}}$ \\
\hline & Dincer & $6.56^{\mathrm{b}}$ & $6.90^{\mathrm{ab}}$ & $6.73^{\mathrm{b}}$ & $2.26^{\mathrm{bcd}}$ & $2.26^{\mathrm{c}}$ & $2.26^{\mathrm{cd}}$ \\
\hline & Balci & $6.86^{\mathrm{a}}$ & $7.16^{\mathrm{a}}$ & $7.01^{\mathrm{a}}$ & $2.46^{\mathrm{a}}$ & $2.60^{\mathrm{a}}$ & $2.53^{\mathrm{a}}$ \\
\hline & Yenice & $5.76^{\mathrm{c}}$ & $5.96^{\mathrm{f}}$ & $5.86^{\mathrm{d}}$ & $2.36^{\mathrm{ab}}$ & $2.40^{\mathrm{b}}$ & $2.38^{b c}$ \\
\hline \multirow{4}{*}{ Spring } & Remzibey & $5.80^{\mathrm{c}}$ & $6.10^{\text {ef }}$ & $5.95^{\mathrm{d}}$ & $2.30^{\mathrm{bc}}$ & $2.40^{\mathrm{b}}$ & $2.35^{\mathrm{cd}}$ \\
\hline & Dincer & $6.50^{\mathrm{b}}$ & $6.50^{\mathrm{cd}}$ & $6.50^{\mathrm{bc}}$ & $2.16^{\mathrm{d}}$ & $2.10^{\mathrm{d}}$ & $2.13^{\mathrm{e}}$ \\
\hline & Balci & $6.50^{\mathrm{b}}$ & $6.66^{\mathrm{bc}}$ & $6.58^{\mathrm{bc}}$ & $2.20^{\mathrm{cd}}$ & $2.30^{\mathrm{bc}}$ & $2.25^{\mathrm{cd}}$ \\
\hline & Yenice & $5.70^{\mathrm{c}}$ & $6.16^{\mathrm{def}}$ & $5.93^{\mathrm{d}}$ & $2.36^{\mathrm{ab}}$ & $2.60^{\mathrm{a}}$ & $2.48^{\mathrm{ab}}$ \\
\hline \multicolumn{8}{|c|}{ Years } \\
\hline & & $6.28^{\mathrm{b}}$ & $6.47^{\mathrm{a}}$ & & $2.32^{\mathrm{b}}$ & $2.37^{\mathrm{a}}$ & \\
\hline \multicolumn{8}{|c|}{ Sowing time } \\
\hline Winter & & $6.44^{\mathrm{a}}$ & $6.60^{\mathrm{a}}$ & $6.52^{\mathrm{a}}$ & $2.39^{\mathrm{b}}$ & $2.40^{\mathrm{a}}$ & $2.40^{\mathrm{a}}$ \\
\hline Summer & & $6.12^{\mathrm{b}}$ & $6.35^{\mathrm{b}}$ & $6.24^{\mathrm{b}}$ & $2.25^{\mathrm{a}}$ & $2.35^{\mathrm{b}}$ & $2.30^{\mathrm{b}}$ \\
\hline \multicolumn{8}{|c|}{ Varieties } \\
\hline Remzibey & & $6.18^{c}$ & $6.23^{\mathrm{b}}$ & $6.20^{c}$ & $2.38^{\mathrm{a}}$ & $2.38^{\mathrm{b}}$ & $2.38^{\mathrm{a}}$ \\
\hline Dincer & & $6.53^{\mathrm{b}}$ & $6.70^{\mathrm{a}}$ & $6.61^{\mathrm{b}}$ & $2.21^{\mathrm{b}}$ & $2.18^{\mathrm{c}}$ & $2.20^{\mathrm{b}}$ \\
\hline Balci & & $6.68^{\mathrm{a}}$ & $6.91^{\mathrm{a}}$ & $6.80^{\mathrm{a}}$ & $2.33^{\mathrm{a}}$ & $2.45^{\mathrm{ab}}$ & $2.32^{\mathrm{a}}$ \\
\hline Yenice & & $5.73^{\mathrm{d}}$ & $6.06^{\mathrm{b}}$ & $5.90^{\mathrm{d}}$ & $2.36^{\mathrm{a}}$ & $2.50^{\mathrm{a}}$ & $2.43^{\mathrm{a}}$ \\
\hline \multicolumn{8}{|c|}{ Significance status } \\
\hline Years (Y) & & - & - & $* *$ & - & - & * \\
\hline Sowing time (ST) & & $* *$ & $* *$ & $* *$ & $* *$ & * & $* *$ \\
\hline Varieties (V) & & $* *$ & $* *$ & $* *$ & $* *$ & $* *$ & $* *$ \\
\hline $\mathrm{Y} \times \mathrm{ST}$ & & - & - & $*$ & - & - & $*$ \\
\hline $\mathrm{Y} \times \mathrm{V}$ & & - & - & ns & - & - & $*$ \\
\hline $\mathrm{ST} \times \mathrm{V}$ & & $* *$ & ns & $* *$ & $*$ & $* *$ & $* *$ \\
\hline $\mathrm{Y} \times \mathrm{ST} \times \mathrm{V}$ & & - & - & ns & - & - & $*$ \\
\hline
\end{tabular}

${ }^{*}$ Significant at level $0.05 ;{ }^{* *}$ significant at level 0.01 . Means shown by the different letters within a column are statistically different.

Kucuk [20], the lowest oleic acid production rate was found in the Yenice variety with the highest rate in the Remzibey variety. However, the opposite pattern was found for linoleic acid production rates.

The aim of this research is to examine the protein and oil production rates and fatty acid composition and their correlation in four safflower varieties sown in autumn and spring.

\section{Materials and Methods}

This research was conducted in the trial fields of Uludag University, Mustafakemalpasa Vocational School $\left(40^{\circ} 02^{\prime} \mathrm{N}\right.$, $28^{\circ} 23^{\prime} \mathrm{E}$ ), from 2013 to 2015 . The trial field soils are light alkaline ( $\mathrm{pH} 7.8)$ that are moderate in terms of lime $\left(81 \mathrm{~kg} \mathrm{ha}^{-1}\right)$, low in salt content $\left(0.48 \mathrm{dSm}^{-1}\right)$, moderate in organic matter (1.9\%), poor in total nitrogen $(0.20 \%)$, and rich in potassium $\left(1395 \mathrm{~kg} \mathrm{ha}^{-1}\right)$.

The month of June was determined to be the intensive seed setting period. The precipitation was higher in 2014 compared to 2015 and the yearly averages $(94.0,45.4$, and $33.8 \mathrm{~mm}$, resp.). Likewise, the average air temperature measured for the same month varied insignificantly among trial years and the long-term yearly averages $(22.5,21.6$, and $22.1 \mathrm{~mm}$, resp.).

Two different sowing times (spring and autumn) and four different varieties (Remzibey Dincer, Balci, and Yenice) were used in the study. The varieties were provided by the Eskisehir Transitional Zone Agricultural Research Institute, of which the Remzibey and Balci varieties are spiny, and the other varieties are spineless.

The autumn sowings on October 25 of 2013 and 2014 and the spring sowings on March 20 of 2014 and 2015 were performed by hand. In the trial, the row spacing was $40 \mathrm{~cm}$, and the in-row spacing was $15 \mathrm{~cm}$. There were 5 rows in each plot, and the area of each plot was $10 \mathrm{~m}^{2}(5 \mathrm{~m} \times 2 \mathrm{~m})$. The trial was implemented as split plots in a completely randomized block experimental design with 3 replications; sowing times and varieties were the main and subplots, respectively.

Canola was preplanted in the trial area. For the autumn sowing, soil preparation included the application of $150 \mathrm{~kg}$ 20-20-0 fertilizer and $150 \mathrm{~kg}$ ammonium nitrate fertilizer (33\%) per hectare before rain in mid-March. The spring sowing also used $150 \mathrm{~kg}$ 20-20-0 fertilizer and $150 \mathrm{~kg}$ ammonium nitrate fertilizer (33\%) per hectare before rain in early May. 
TABLE 3: Oleic and linoleic acid composition of safflower seeds sown in the autumn and spring.

\begin{tabular}{|c|c|c|c|c|c|c|c|}
\hline \multirow{2}{*}{ Sowing time } & \multirow{2}{*}{ Varieties } & \multicolumn{3}{|c|}{ Oleic acid composition } & \multicolumn{3}{|c|}{ Linoleic acid composition } \\
\hline & & 2014 & 2015 & 2014-15 & 2014 & 2015 & 2014-15 \\
\hline \multirow{4}{*}{ Autumn } & Remzibey & $16.73^{\mathrm{b}}$ & $36.20^{\mathrm{a}}$ & $26.46^{\mathrm{a}}$ & $72.93^{c}$ & $53.50^{\mathrm{d}}$ & $63.21^{b}$ \\
\hline & Dincer & $13.10^{\mathrm{cd}}$ & $20.50^{c}$ & $16.80^{\mathrm{b}}$ & $77.13^{\mathrm{b}}$ & $68.73^{\mathrm{b}}$ & $72.93^{\mathrm{a}}$ \\
\hline & Balci & $12.36^{\text {cde }}$ & $14.53^{\mathrm{d}}$ & $13.45^{\mathrm{b}}$ & $77.40^{\mathrm{b}}$ & $74.63^{\mathrm{a}}$ & $76.01^{\mathrm{a}}$ \\
\hline & Yenice & $11.36^{\mathrm{de}}$ & $13.03^{\mathrm{d}}$ & $12.20^{\mathrm{b}}$ & $79.60^{\mathrm{a}}$ & $77.63^{\mathrm{a}}$ & $78.61^{\mathrm{a}}$ \\
\hline \multirow{4}{*}{ Spring } & Remzibey & $33.26^{\mathrm{a}}$ & $29.90^{\mathrm{b}}$ & $31.58^{\mathrm{a}}$ & $57.50^{\mathrm{d}}$ & $60.66^{\mathrm{c}}$ & $59.08^{\mathrm{b}}$ \\
\hline & Dincer & $13.50^{\mathrm{c}}$ & $12.03^{\mathrm{d}}$ & $12.76^{\mathrm{b}}$ & $76.80^{\mathrm{b}}$ & $78.43^{\mathrm{a}}$ & $77.61^{\mathrm{a}}$ \\
\hline & Balci & $16.43^{\mathrm{b}}$ & $15.90^{\mathrm{d}}$ & $16.16^{\mathrm{b}}$ & $73.63^{c}$ & $74.36^{\mathrm{a}}$ & $74.00^{\mathrm{a}}$ \\
\hline & Yenice & $11.00^{\mathrm{e}}$ & 13.16 & $12.08^{\mathrm{b}}$ & $80.00^{\mathrm{a}}$ & $76.66^{\mathrm{a}}$ & $78.33^{\mathrm{a}}$ \\
\hline \multicolumn{8}{|c|}{ Years } \\
\hline & & $15.97^{\mathrm{b}}$ & $19.40^{\mathrm{a}}$ & & $74.37^{\mathrm{a}}$ & $70.57^{\mathrm{b}}$ & \\
\hline \multicolumn{8}{|c|}{ Sowing time } \\
\hline Winter & & $13.39^{\mathrm{b}}$ & $21.06^{\mathrm{a}}$ & 17.22 & $76.76^{\mathrm{a}}$ & $68.62^{\mathrm{b}}$ & 72.69 \\
\hline Summer & & $18.55^{\mathrm{a}}$ & $17.75^{\mathrm{b}}$ & 18.15 & $71.98^{\mathrm{b}}$ & $72.53^{\mathrm{a}}$ & 72.25 \\
\hline \multicolumn{8}{|c|}{ Varieties } \\
\hline Remzibey & & $25.00^{\mathrm{a}}$ & $33.05^{\mathrm{a}}$ & $29.02^{\mathrm{a}}$ & $63.21^{\mathrm{d}}$ & $59.08^{c}$ & $61.15^{c}$ \\
\hline Dincer & & $13.30^{c}$ & $16.26^{\mathrm{b}}$ & $14.78^{\mathrm{b}}$ & $72.93^{c}$ & $77.61^{\mathrm{ab}}$ & $75.27^{\mathrm{b}}$ \\
\hline Balci & & $14.40^{\mathrm{b}}$ & $15.21^{\mathrm{b}}$ & $14.80^{\mathrm{b}}$ & $76.01^{b}$ & $74.00^{\mathrm{b}}$ & $75.00^{\mathrm{b}}$ \\
\hline Yenice & & $11.18^{\mathrm{d}}$ & $13.10^{\mathrm{b}}$ & $12.14^{\mathrm{c}}$ & $78.61^{\mathrm{a}}$ & $78.33^{\mathrm{a}}$ & $78.47^{\mathrm{a}}$ \\
\hline \multicolumn{8}{|c|}{ Significance status } \\
\hline Years (Y) & & - & - & $* *$ & - & - & $* *$ \\
\hline Sowing time (ST) & & $* *$ & $* *$ & ns & $* *$ & $* *$ & ns \\
\hline Varieties (V) & & $* *$ & $* *$ & $* *$ & $* *$ & $* *$ & $* *$ \\
\hline $\mathrm{Y} \times \mathrm{ST}$ & & - & - & $* *$ & - & - & $* *$ \\
\hline $\mathrm{Y} \times \mathrm{V}$ & & - & - & $* *$ & - & - & $* *$ \\
\hline $\mathrm{ST} \times \mathrm{V}$ & & $* *$ & $*$ & $* *$ & $* *$ & $* *$ & $* *$ \\
\hline $\mathrm{Y} \times \mathrm{ST} \times \mathrm{V}$ & & - & - & $* *$ & - & - & $* *$ \\
\hline
\end{tabular}

${ }^{*}$ Significant at level $0.05 ;{ }^{* *}$ significant at level 0.01 . Means shown by the different letters within a column are statistically different.

Irrigation was not implemented for either sowing time, and weed management was performed by hand hoe if necessary.

Using clear seed samples from each replicate, protein production rates, oil production rates, and fatty acid composition were determined in the laboratory of the Sila Oil Factory, which is located in the town of Karacabey, Bursa Province. Protein and oil production rates and the fatty acid composition of the seeds were quantified using Kjeldahl, Soxhlet, and gas chromatography apparatuses, respectively. Using the SPSS statistical program, an analysis of variance was applied to the data, and significant differences were grouped according to Duncan's method.

\section{Research Results and Discussion}

Safflower seed protein and oil production rates; palmitic and stearic acids from saturated fatty acids; and oleic, linoleic, and linolenic acids from unsaturated fatty acids were examined by individual years and as averages for all years.
3.1. Protein Production Rate. According to the results, which were calculated as yearly averages, significant differences were found among the effects of year, variety, and the interactions between sowing time $\times$ variety, year $\times$ sowing time, and year $\times$ sowing time $\times$ variety on protein production rates. However, the effects of sowing time and the year $\times$ variety interaction were insignificant.

The averages given in Table 1 show that sowing time did not affect protein production rates, and the highest values were found in the Yenice (17.45\%) and Balci (17.10\%) varieties. The Remzibey and Dincer varieties had the lowest values. The protein production rate in the first trial year was higher than that of the second trial year (16.87\% and $16.10 \%$, resp.).

When protein production was evaluated in terms of sowing time and variety, the Balci (18.08\%) and Yenice (16.91\%) varieties sown in the spring had the statistically highest values. The Remzibey variety sown in the autumn had the lowest value of $15.20 \%$. A significant year $\times$ sowing time $\times$ variety interaction suggests that the effects of the varieties varied with year and sowing time. Similar results 
TABLE 4: Linolenic acid rates composition of safflower seeds sown in the autumn and spring.

\begin{tabular}{|c|c|c|c|c|}
\hline \multirow{2}{*}{ Sowing time } & \multirow{2}{*}{ Varieties } & \multicolumn{3}{|c|}{ Linolenic acid composition } \\
\hline & & 2014 & 2015 & 2014-15 \\
\hline \multirow{4}{*}{ Autumn } & Remzibey & $0.13^{\mathrm{a}}$ & $0.13^{\mathrm{bc}}$ & $0.13^{\mathrm{ab}}$ \\
\hline & Dincer & $0.12^{\mathrm{b}}$ & $0.18^{\mathrm{a}}$ & $0.15^{\mathrm{a}}$ \\
\hline & Balci & $0.10^{\mathrm{d}}$ & $0.13^{\mathrm{bc}}$ & $0.11^{\mathrm{b}}$ \\
\hline & Yenice & $0.12^{\mathrm{b}}$ & $0.13^{\mathrm{bc}}$ & $0.12^{\mathrm{ab}}$ \\
\hline \multirow{4}{*}{ Spring } & Remzibey & $0.10^{\mathrm{d}}$ & $0.15^{\mathrm{b}}$ & $0.13^{\mathrm{ab}}$ \\
\hline & Dincer & $0.11^{\mathrm{c}}$ & $0.14^{\mathrm{b}}$ & $0.12^{\mathrm{ab}}$ \\
\hline & Balci & $0.10^{\mathrm{d}}$ & $0.11^{c}$ & $0.11^{\mathrm{b}}$ \\
\hline & Yenice & $0.12^{\mathrm{b}}$ & $0.13^{\mathrm{bc}}$ & $0.12^{\mathrm{ab}}$ \\
\hline \multicolumn{5}{|c|}{ Years } \\
\hline & & $0.11^{\mathrm{b}}$ & $0.14^{\mathrm{a}}$ & \\
\hline \multicolumn{5}{|c|}{ Sowing time } \\
\hline Winter & & $0.12^{\mathrm{a}}$ & 0.14 & $0.13^{\mathrm{a}}$ \\
\hline Summer & & $0.11^{\mathrm{b}}$ & 0.13 & $0.12^{\mathrm{b}}$ \\
\hline \multicolumn{5}{|c|}{ Varieties } \\
\hline Remzibey & & $0.13^{\mathrm{b}}$ & $0.13^{\mathrm{a}}$ & $0.13^{\mathrm{b}}$ \\
\hline Dincer & & $0.15^{\mathrm{a}}$ & $0.12^{\mathrm{ab}}$ & $0.14^{\mathrm{a}}$ \\
\hline Balci & & $0.11^{\mathrm{d}}$ & $0.11^{\mathrm{b}}$ & $0.11^{\mathrm{c}}$ \\
\hline Yenice & & $0.12^{\mathrm{c}}$ & $0.12^{\mathrm{ab}}$ & $0.12^{\mathrm{bc}}$ \\
\hline \multicolumn{5}{|c|}{ Significance status } \\
\hline Years (Y) & & - & - & ** \\
\hline Sowing time (ST) & & $* *$ & ns & $*$ \\
\hline Varieties (V) & & $* *$ & ** & $* *$ \\
\hline $\mathrm{Y} \times \mathrm{ST}$ & & - & - & ns \\
\hline $\mathrm{Y} \times \mathrm{V}$ & & - & - & $* *$ \\
\hline $\mathrm{ST} \times \mathrm{V}$ & & $* *$ & * & ns \\
\hline $\mathrm{Y} \times \mathrm{ST} \times \mathrm{V}$ & & - & - & $* *$ \\
\hline
\end{tabular}

*Significant at level $0.05 ;{ }^{* *}$ significant at level 0.01 . Means shown by the different letters within a column are statistically different.

were reported by [14, 21-23] Tuncturk et al. (2005), Atabey (2009), Keles (2010), and Golkar et al. (2011).

3.2. Oil Production Rate. The effects of year, sowing time, variety, and all of the interactions had significantly different effects on the oil production rates of safflower seed. The highest rate was found in the Balci variety, with a value of $31.99 \%$, while the lowest values occurred in the Dincer and Remzibey varieties (24.58 and $25.00 \%$, resp.). A higher oil content value was obtained from the autumn sowing time compared to the spring sowing time (27.42 and $26.10 \%$, resp.), and the yearly value for 2014 was higher than that from 2015 ( 27.95 and $25.57 \%$, resp.). When examined in terms of sowing time and variety, the highest oil contents were identified in the spring and autumn sowings of the Balci variety $(32.20$ and $31.78 \%$, resp.). The lowest value was found in the Dincer variety sown in the autumn (23.05\%). The Balci variety had the highest overall oil content as well as the highest in the individual years (Table 1).
Keles [23] and Camas et al. [24] found oil content values that varied from 24.0 to $28.0 \%$ and from 25.60 to $31.83 \%$, respectively. Our findings agree closely with those reported by $[12,25-30]$. However, in contrast to the results of our trial, Yau [17], Esendal et al. [18], and Ada [31] concluded that the most suitable sowing time for high oil rates is autumn.

3.3. Saturated Fatty Acid Composition. According to the analysis of variance, year, sowing time, and variety, the year $x$ sowing time and sowing time $x$ variety interactions were found to significantly affect palmitic acid production rates, while the effects of the year $\times$ variety and year $\times$ sowing time $x$ variety interactions were insignificant. However, the effects of all of the examined characteristics on stearic acid production rates were found to be significant.

Palmitic acid production rates ranged from 5.93 to $7.01 \%$, and, at $6.52 \%$, the autumn sowing yielded the highest rate compared to the spring sowing. In terms of varieties, the production of the Balci variety was highest at $6.80 \%$, and the Yenice variety was lowest with $5.90 \%$. The rates that were determined for 2015 were higher than for 2014. The Balci variety sown in the spring was ranked highest at $7.01 \%$, and the Remzibey variety sown in the spring and the Yenice variety sown in both the autumn and spring were lowest. For the autumn sowing, the Balci variety yielded the highest palmitic acid values in both 2014 and 2015 (Table 2).

The minimum and maximum values for stearic acid presented in Table 2 are 2.13 and 2.53\%, respectively, and the autumn sowing produced a higher value than the spring planting. Two varietal groups were identified; the Yenice, Remzibey, and Balci varieties constituted the first group while the Dincer variety made up the second and lowest-yielding group. The Balci variety sown in the autumn provided the highest values in terms of the averages for all years and the individual years. For the spring sowing, the Dincer variety had the lowest value. The effect of the year $\times$ sowing time $\times$ variety interaction was found to be statistically significant, suggesting that stearic acid values differed significantly with year, planting time, and variety.

Naghab et al. [19] concluded that palmitic and stearic acid production rates are higher with autumn sowing, and this supports the findings of our trial. Similar results were also reported by some other researchers $[2,16,22,32,33]$.

3.4. Unsaturated Fatty Acid Composition. According to the data summarized in Table 3, year, variety, and all of the interactions, except sowing time, had statistically significant different effects on the oleic acid and linoleic acid from unsaturated fatty acids. In contrast, linolenic acid production rates were significantly affected by all of the factors, except for the year $\times$ sowing time and sowing time $\times$ variety interactions.

With a rate of $29.02 \%$, the highest oleic acid content was found in the Remzibey variety followed by the Dincer and Balci varieties, and the Yenice variety had the lowest rate (12.14\%). Sowing time had no effect on oleic acid composition. Compared to 2014 with a rate of $15.97 \%$, the rate in 2015 was higher with a value of $19.40 \%$. While the 
TABLE 5: Correlation coefficients among protein, oil, and fatty acid composition of safflower seeds.

\begin{tabular}{|c|c|c|c|c|c|c|c|}
\hline Traits & Protein rate & Oil rate & $\begin{array}{c}\text { Palmitic acid } \\
(\mathrm{C} 16: 0)\end{array}$ & $\begin{array}{c}\text { Stearic acid } \\
(\mathrm{C} 18: 0)\end{array}$ & $\begin{array}{c}\text { Oleic acid } \\
(\mathrm{C} 18: 1)\end{array}$ & $\begin{array}{c}\text { Linoleic acid } \\
(\mathrm{C} 18: 2)\end{array}$ & $\begin{array}{c}\text { Linolenic acid } \\
(\mathrm{C} 18: 3)\end{array}$ \\
\hline Protein rate & 1.000 & $0.476^{* *}$ & $-0.305^{*}$ & -0.040 & $-0.490^{* *}$ & $0.520^{* *}$ & $-0.438^{* *}$ \\
\hline Oil rate & & 1.000 & 0.227 & 0.068 & -0.262 & 0.262 & $-0.728^{* *}$ \\
\hline Palmitic acid (C16:0) & & & 1.000 & 0.101 & -0.165 & 0.101 & 0.213 \\
\hline Stearic acid (C18:0) & & & & 1.000 & -0.014 & -0.015 & 0.085 \\
\hline Oleic acid (C18:1) & & & & & 1.000 & $-0.997^{* *}$ & 0.172 \\
\hline Linoleic acid (C18:2) & & & & & & 1.000 & -0.197 \\
\hline Linolenic acid (C18:3) & & & & & & & 1.000 \\
\hline
\end{tabular}

${ }^{*}$ Significant at level $0.05 ;{ }^{* *}$ significant at level 0.01 .

Remzibey variety sown in both spring and autumn yielded the highest rate, the other varieties were grouped second and last as above, also for both sowing times. Additionally, the results for the individual years exhibit parallel trends to the averages for all years.

The production of linoleic acid in safflower seeds varied from 78.61 to $59.08 \%$, and the linoleic acid content in 2015 was higher than in 2014 (74.37 and 70.57\%, resp.). According to the averages for all years, the highest and lowest rates were found in the Yenice varieties with $78.47 \%$ and in the Remzibey variety with $61.15 \%$, respectively. Sowing time had no effect on linoleic acid composition. When the performance of the varieties was analyzed according to sowing time, the highest rates were obtained for the Yenice, Balci, and Dincer varieties sown in the spring and autumn, and the lowest rate was realized in the both the spring and autumn in the Remzibey variety. The significant interactions revealed significant differences among the varieties according to sowing time and year (Table 3 ).

Linolenic acid production rates, which were ranked third among the investigated unsaturated fatty acids, were found to be between 0.11 and $0.15 \%$. Higher rates were found in the seeds of safflowers sown in the autumn than in seeds sown in the spring. The Dincer variety, with a rate of $0.14 \%$, and the Balci variety, with a rate of $0.11 \%$, yielded the highest and lowest values, respectively. Linolenic acid was found in higher proportions in the second year of the trial compared to the first, and when the rates of linolenic acid production were evaluated in terms of planting time and variety, the highest content was found in the Dincer variety sown in the autumn with a rate of $0.15 \%$. The lowest value, a rate of $0.11 \%$, was found in the Balci variety sown in the spring (Table 4 ).

The results of Arslan and Kucuk [20], Atabey [22], and Matthaus et al. [34] are very similar to the results of our research. However, the findings of Naghab et al. [19] (2011) do not support ours because those authors suggested that autumn sowing is the most suitable sowing time for high oleic acid production; according to the averages of all of the years of our study, oleic acid rates were not affected by sowing time.

3.5. Oil Production Rate and Correlation Coefficients among Other Examined Traits. The Pearson correlation coefficients calculated among protein and oil production rates and fatty acid composition are provided in Table 5.

According to these calculations, the protein production rate was significantly negatively correlated with the production of palmitic acid $\left(r=-0.305^{*}\right)$, oleic acid $(r=$ $\left.-0.490^{* *}\right)$, and linolenic acid $\left(r=0.438^{* *}\right)$ and positively significantly correlated with oil $\left(r=0.476^{* *}\right)$ and linoleic acid production $\left(r=0.520^{* *}\right)$. The oil production rate was positively significantly correlated $\left(0.476^{* *}\right)$ with protein rate and negatively significantly correlated $\left(r=-0.728^{* *}\right)$ with linolenic acid. In addition, a very strong negative correlation $\left(r=-0.997^{* *}\right)$ was found between oleic acid and linoleic acid, and this finding shows that as rates of oleic acid increase, rates of linoleic acid decrease. Other negative or positive correlation coefficients were not significant.

Arslan [32], Guan et al. [33], and Vosoughkia et al. [35] found significant negative relationships between oleic acid and linoleic acid that are very similar to the results of our trial. Golkar et al. [14] concluded that there is a positive and significant relationship between the production rates of palmitic acid and protein. Additionally, Vosoughkia et al. [35] found a significant negative correlation between linolenic acid and oil production rates, which agrees with our findings.

\section{Conclusion}

In conclusion, safflower can be sown in the autumn and spring in Mustafakemalpasa, but a higher oil rate was obtained from spring sowing. The Balci variety was more suitable than the other three varieties for oil production. The production rates of oleic acid, which is an important fatty acid component, were not affected by sowing time, and the highest rate was found in the Remzibey variety.

\section{Competing Interests}

The author declares that they have no competing interests.

\section{Acknowledgments}

This paper was edited by American Journal Experts (AJE), under Reference no. UU_943. 


\section{References}

[1] V. Vorpsi, F. Harizaj, N. Bardhi, V. Vladi, and E. Dodona, "Carthamus tinctorius L., the quality of safflower seeds cultivated in Albania," Research Journal of Agricultural Science, vol. 42, no. 1, pp. 326-331, 2010.

[2] B. Cosge, B. Gurbuz, and M. Kiralan, "Oil content and fatty acid composition of some (Carthamus tinctorius L.) varieties sown in spring and winter," International Journal of Natural and Engineering Sciences, vol. 1, pp. 11-15, 2007.

[3] M. M. Majidi, V. Tavakoli, A. Mirlohi, and M. R. Sabzalian, "Wild safflower species (Carthamus oxyacanthus Bieb.): a possible source of drought tolerance for arid environments," Australian Journal of Crop Science, vol. 5, no. 8, pp. 1055-1063, 2011.

[4] P. Golkar, A. Arzani, and A. M. Rezaei, "Inheritance of flower colour and spinelessness in safflower (Carthamus tinctorius L.)," Journal of Genetics, vol. 89, no. 2, pp. 259-262, 2010.

[5] S. D. Koutroubas and D. K. Papadoska, "Adaptation, grain yield and oil content of safflower in Greece," in Proceedings of the 6th International Safflower Conference, pp. 161-167, Istanbul, Turkey, June 2005.

[6] FAO, Statistical Yearbook, 2014.

[7] R. Keles and O. Oztürk, "Effect of different dowing dates on the seed yield and quality of safflower," Journal of Agricultural Sciences, vol. 5, no. 1, pp. 112-117, 2012.

[8] H. Koc, G. Gumuscu, A. Ustun et al., "Konya şartlarında aspir ekim zamanının belirlenmesi," in Türkiye VIII. Tarla Bitkileri Kongresi, Endüstri Bitkileri, pp. 103-106, Hatay, Turkey, 2009 (Turkish).

[9] B. Yılmazlar and N. Bayraktar, "Konya şartlarında farklı ekim zamanlarının bazı aspir çeşitlerinde önemli tarımsal karakterler üzerine ve verime etkisi," in Proceedings of the Türkiye VIII, Tarla Bitkileri Kongresi, pp. 172-177, Endüstri Bitkileri, Hatay, Turkey, 2009 (Turkish).

[10] H. Yeilaghi, A. Arzani, M. Ghaderian, R. Fotovat, M. Feizi, and S. S. Pourdad, "Effect of salinity on seed oil content and fatty acid composition of safflower (Carthamus tinctorius L.) genotypes," Food Chemistry, vol. 130, no. 3, pp. 618-625, 2012.

[11] R. Liu, W. Wu, Y. Zheng, Y. Yang, L. Chan, and C. Huang, "Analysis of the oil and its fatty acids percentage of the seed of 48 safflower accessions," Southwest China Journal of Agricultural Sciences, vol. 19, no. 5, pp. 920-928, 2006.

[12] U. Gecgel, M. Demirci, E. Esendal, and M. Tasan, "Fatty acid composition of the oil from developing seeds of different varieties of safflower (Carthamus tinctorius L.)," Journal of the American Oil Chemists' Society, vol. 84, no. 1, pp. 47-54, 2007.

[13] I. M. Mateas, V. Tabara, A. Albai, and S. Nita, "The oil content in safflower (Carthamus tinctorius L.) under the influence of sowing," Research Journal of Agricultural Science, vol. 46, no. 3 , pp. 29-31, 2014.

[14] P. Golkar, A. Arzani, and A. M. Rezaei, "Genetic variation in safflower (Carthamus tinctorious L.) for seed quality-related traits and inter-simple sequence repeat (ISSR) markers," International Journal of Molecular Sciences, vol. 12, no. 4, pp. 2664-2677, 2011.

[15] M. Mirshekari, N. Majnounhosseini, R. Amiri, A. Moslehi, and O. R. Zandvakili, "Effects of sowing date and irrigation treatment on safflower seed quality," Journal of Agricultural Sciences and Techology, vol. 15, pp. 505-515, 2013.

[16] M. R. Sabzalian, G. Saeidi, and A. Mirlohi, "Oil content and fatty acid composition in seeds of three safflower species," Journal of the American Oil Chemists' Society, vol. 85, no. 8, pp. 717-721, 2008.

[17] S. K. Yau, "Winter versus spring sowing of rain-fed safflower in a semi-arid, high-elevation Mediterranean environment," European Journal of Agronomy, vol. 26, no. 3, pp. 249-256, 2007.

[18] E. Esendal, B. Arslan, and C. Pasa, "Effect of winter and spring sowing on yield and planttraits of afflower (Carthamus tinctorius L.)," in Proceedings of the 7th International Safflower Conference, Wagga Wagga, Australia, November 2008.

[19] M. G. Naghab, A. R. Ddakhah, and A. M. Asaadi, "Effect of autumn and spring sowing on yield oil content and fatty acid composition of safflower (Carthamus tinctorius L.) cultivars in Shirvan region," in Proceedings of the 59th International Congress and Annual Meeting of the Society for Medicinal Plant and Natural Product Research, 2011.

[20] B. Arslan and M. Kucuk, "Oil content and fatty acid composition of some safflower cultivars in Van (Turkey)," in Proceedings of the 6th International Safflower Conference, pp. 167-175, Istanbul, Turkey, 2005.

[21] M. Tuncturk, B. Arslan, and V. Ciftci, "Korelasyon ve reaksiyon katsayisi kullanilarak aspir karakterleri arasindaki iliksiler," in Türkiye VI. Uluslararası Aspir Konferansi, pp. 199-204, Istanbul, Turkey, 2005 (Turkish).

[22] E. Atabey, The Effects of different sowing dates on some agricultural properties and biodiesel quality of three different varieties of safflower [M.S. thesis], Selçuk University, Natural Sciences Institute, Field Crops Department, 2009.

[23] R. Keles, Effects of different sowing dates on the yield, yield components and quality on some safflower (Carthamus tinctorius L.) cultivars [M.S. thesis], Selcuk University, Institute of Natural and Applied Sciences, Field Crops Department, Konya, Turkey, 2010.

[24] N. Camas, C. Cirak, and E. Esendal, "Seed yield, oil content and fatty acids composition of safflower (Carthamus tinctorius L.) grown in Northern Turkey Conditions," Journal of Faculty of Agriculture, O.M.U, vol. 22, no. 1, pp. 98-104, 2007.

[25] E. Ashrafi and K. Razmjoo, "Effect of irrigation regimes on oil content and composition of safflower (Carthamus tinctorius 1.) cultivars," Journal of the American Oil Chemists' Society, vol. 87, no. 5, pp. 499-506, 2010.

[26] A. H. Omidi, H. Khazaei, P. Monneveux, and F. Stoddard, "Effect of cultivar and water regime on yield and yield components in safflower (Carthamus tinctorius L.)," Turkish Journal of Field Crops, vol. 17, no. 1, pp. 10-15, 2012.

[27] Y. Coskun, "Winter and summer sowing facilities of safflower (Carthamus tinctorius L.)," Turkish Journal of Agricultural and Natural Sciences, vol. 1, no. 4, pp. 462-468, 2014.

[28] D. Katar, I. Subasi, and Y. Arslan, "Effect of different maturity stages in safflower (Carthamus tinctorius L.) on oil content and fatty acid composition," Suleyman Demirel University, Journal of Agriculture Faculty, vol. 9, no. 2, pp. 83-92, 2014.

[29] M. D. Kaya, S. Bayramin, E. G. Kulan, and I. Ozasik, "Performance of some improved safflower lines under Eskişehir conditions," Journal of Agricultural Faculty of Uludag University, vol. 29, no. 1, pp. 57-65, 2015.

[30] S. D. Koutroubas, D. K. Papakosta, and A. Doitsinis, "Phenotypic variation in physiological determinants of yield in spring sown safflower under Mediterranean conditions," Field Crops Research, vol. 112, no. 2-3, pp. 199-204, 2009.

[31] R. Ada, "Effects of winter and spring sowing on yield components of safflower genotypes," International Journal of Biological, 
Biomolecular, Agricultural, Food and Biotechnological Engineering, vol. 6, pp. 38-42, 2012.

[32] B. Arslan, "The determination of oil content and fatty acid compositions of domestic and exotic safflower (Carthamus tinctorius L.) genotypes and their interactions," Journal of Agronomy, vol. 6, no. 3, pp. 415-420, 2007.

[33] L. L. Guan, W. Wu, and Y. L. Zheng, "Seed oil and fatty acids of different safflower genotypes and their correlations with agronomic traits and photosynthetic parameters," Philippine Agricultural Scientist, vol. 91, no. 4, pp. 383-388, 2008.

[34] B. Matthaus, M. M. Özcan, and F. Y. Al-Juhaimi, "Fatty acid composition and tocopherol profiles of safflower (Carthamus tinctorius L.) seed oils," Natural Product Research, vol. 29, no. 2, pp. 193-196, 2015.

[35] M. Vosoughkia, L. H. Ghareaghag, M. Ghavami, M. Gharachorloo, and B. Delkhosh, "Evaluation of oil content and fatty acid composition in seeds of different genotypes of safflower (Carthamus tinctorius L.)," International Journal of Agricultural Science and Research, vol. 2, no. 1, pp. 59-66, 2011. 

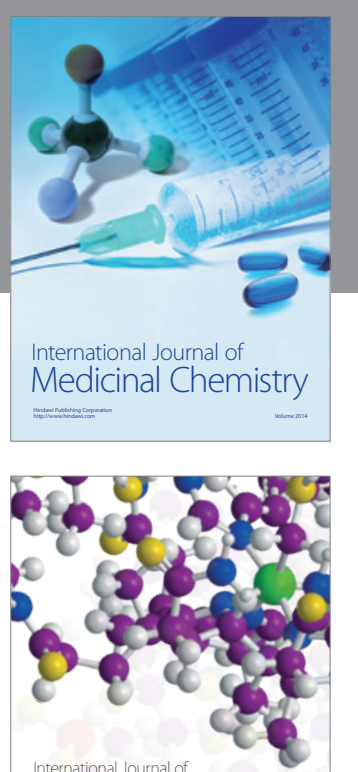

Carbohydrate Chemistry

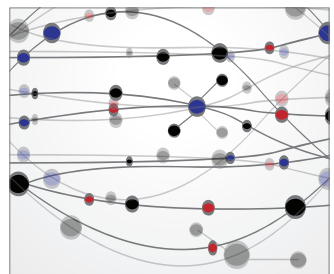

The Scientific World Journal
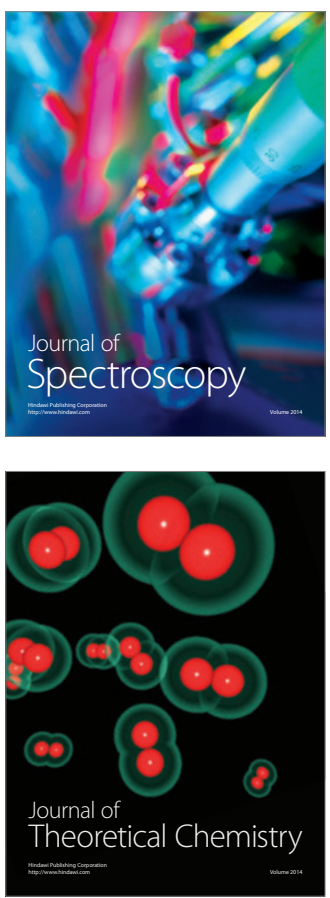
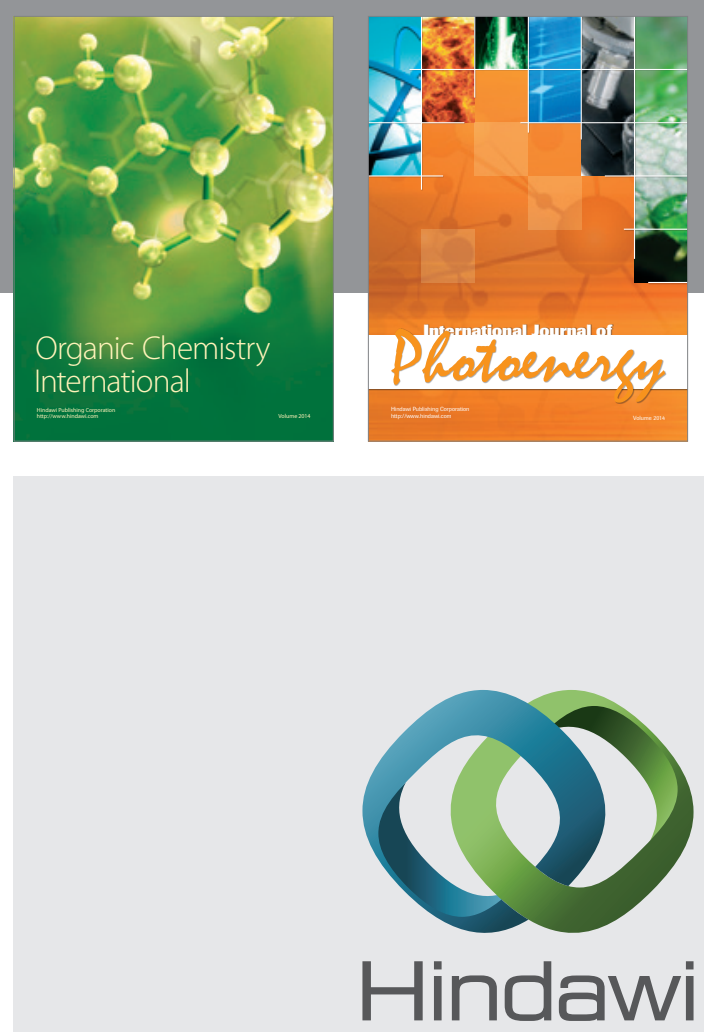

Submit your manuscripts at

http://www.hindawi.com

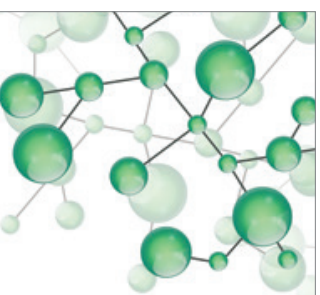

International Journal of

Inorganic Chemistry

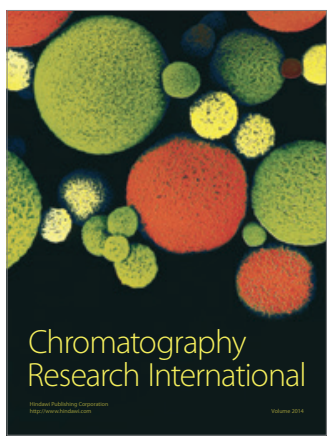

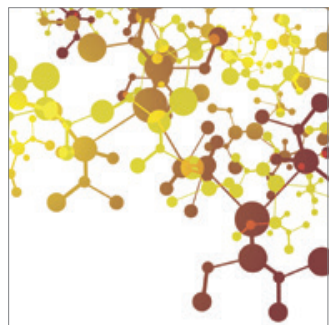

Applied Chemistry
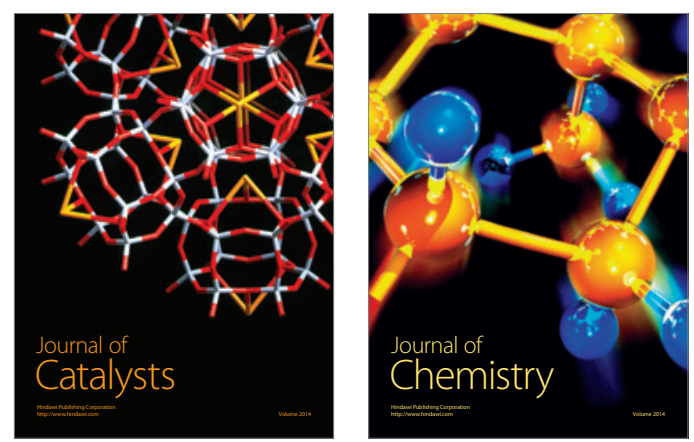
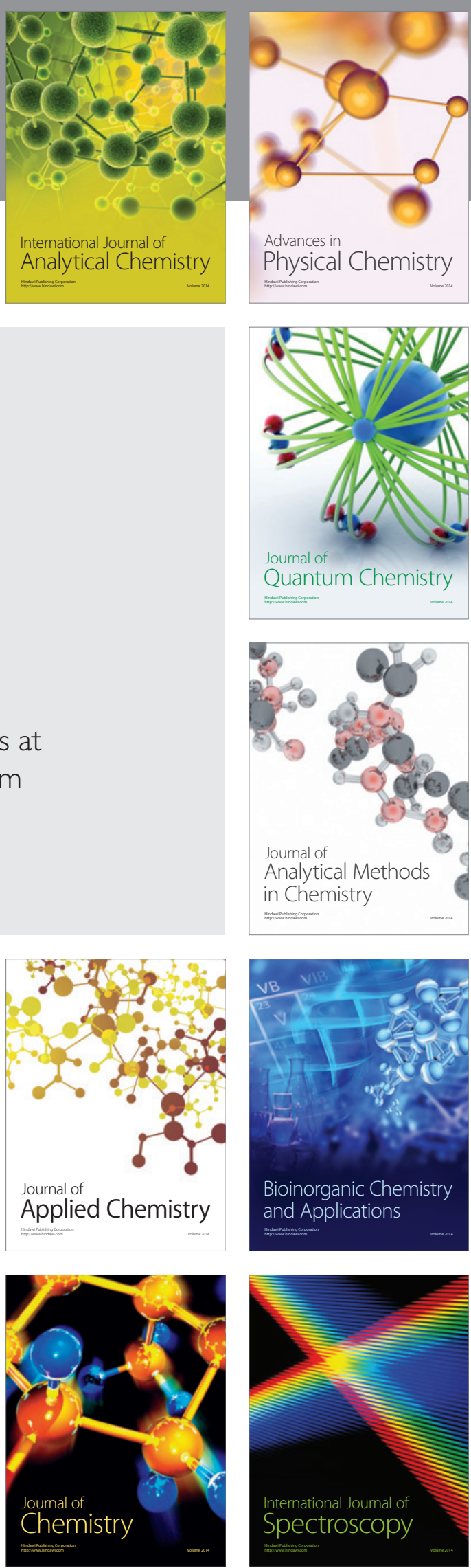